\title{
Pragmatic language dysfunctions in schizophrenia and depression patients - a preliminary study
}

\author{
Zaburzenia pragmatyki języka w grupach pacjentów chorujących na schizofrenię i depresję - \\ badania wstępne
}

\author{
'Chair of Surgery, Department of Neurosurgery, Spine Surgery and Peripheral Nerves Surgery, Medical University of Lodz, Kódź, Poland [the paper was written during research in the Department of Affective \\ and Psychotic Disorders, Medical University of Lodz, Łódź, Poland] \\ ${ }^{2}$ Chair of Neuropsychology, Department of Cognitive Neuropsychology, University of Warsaw, Warsaw, Poland \\ ${ }^{3}$ Chair of Psychiatry, Observation Ward, Central Clinical Hospital of the Medical University of Lodz, Łódź, Poland \\ ${ }^{4}$ Department of Affective and Psychotic Disorders, Medical University of Lodz, Łódź, Poland \\ Correspondence: Agnieszka Pawełczyk, MA, PsyD, Chair of Surgery, Department of Neurosurgery, Spine Surgery and Peripheral Nerves Surgery, Medical University of Lodz, Żeromskiego 113, $90-549$ kódź, \\ Poland, fax: +48 (42) 6333 001, tel.: +48 (42) 6393 551, e-mail: agnieszka.pawelczyk@umed.lodz.pl \\ Drn. hum. Agnieszka Pawełczyk, Katedra Chirurgii, Klinika Neurochirurgii, Chirurgii Kręgosłupa i Nerwów Obwodowych, Uniwersytet Medyczny w Łodzi, ul. Żeromskiego 113, 90-549 Łódź, \\ faks: +48 (42) 6333 001, tel.: +48 (42) 6393 551, e-mail: agnieszka.pawelczyk@umed.lodz.pl
}

\begin{abstract}
Background: Studies do not clarify whether disturbances in pragmatic language skills are specific for schizophrenia or are connected with psychiatric disorders for example mood disorder. The aim of this paper is to investigate if such impairments could be specific to schizophrenia and evaluate their association with the psychopathological symptoms. Method: Eighty-two participants were enrolled: 41 with schizophrenia and 41 with major depression. Pragmatic language skills were assessed by the Polish version of the Right Hemisphere Language Battery, schizophrenia and depression symptoms were evaluated by Positive and Negative Syndrome Scale and the Hamilton Depression Rating Scale. Results: Schizophrenia and depression patients varied in comprehension of implicit information, humour understanding, processing metaphors, understanding prosody and discourse comprehension. Patients with schizophrenia scored significantly lower in all measured skills except for understanding emotional prosody in which they scored higher. A correlation was found between depression and some pragmatic language skills. Conclusions: The results of this preliminary study suggest that pragmatic language skills could be more seriously disturbed in patients with schizophrenia than with depression. They also imply that pragmatic language dysfunctions may be independent of schizophrenia symptoms being a possible trait of the illness. Further studies on pragmatic language skills in mental health groups could help to identify dysfunctions specific for schizophrenia and could give a better understanding of pragmatic disturbances in mental disorders as a whole.
\end{abstract}

Keywords: schizophrenia, depression, pragmatic language, language and communication skills

Streszczenie Wstęp: Badania nie wyjaśniają, czy zaburzenia pragmatycznych umiejętnościach językowych są specyficzne dla schizofrenii, czy są związane z zaburzeniami psychicznymi, na przykład zaburzeniami nastroju. Celem badania było stwierdzenie, czy takie deficyty mogą być specyficzne dla schizofrenii i czy są związane z objawami psychopatologicznymi. Metoda: Do badania włączono 82 uczestników: 41 ze schizofrenią i 41 z depresją. Pragmatyczne zdolności językowe oceniano za pomocą polskiej wersji Baterii Testów do Badania Funkcji Językowych i Komunikacyjnych Prawej Półkuli Mózgu, natomiast objawy schizofrenii i depresji mierzono Skalą Oceny Objawów Pozytywnych i Negatywnych oraz Skalą Oceny Depresji Hamiltona. Wyniki: Pacjenci ze schizofrenią i depresją mieli różny sposób rozumienia informacji ukrytych w tekście, rozumienia humoru, przetwarzania metafor oraz rozumienia prozodii i dyskursu. Pacjenci ze schizofrenią osiągali znacznie niższe wyniki we wszystkich mierzonych umiejętnościach, z wyjątkiem zrozumienia prozodii emocjonalnej, w której osiągnęli wyższe wyniki. Stwierdzono korelację między depresją a niektórymi pragmatycznymi zdolnościami językowymi. Wnioski: Wyniki tego wstępnego badania sugerują, że pragmatyczne zdolności językowe mogą być poważniej zaburzone u pacjentów ze schizofrenią niż z depresją. Wskazują również, że pragmatyczne dysfunkcje językowe mogą być niezależne od objawów 
schizofrenii i mogą stanowić cechę tej choroby. Dalsze badania nad pragmatycznymi zdolnościami językowymi u osób z różnymi zaburzeniami psychicznymi mogą pomóc w rozpoznaniu dysfunkcji charakterystycznych dla schizofrenii, a także umożliwić lepsze zrozumienie zaburzeń pragmatyki języka u pacjentów psychiatrycznych jako grupy.

Słowa kluczowe: schizofrenia, depresja, aspekty pragmatyczne języka, zdolności językowe i komunikacyjne

\section{INTRODUCTION}

$\mathrm{T}$ The term "pragmatic (higher level) language skills" refers to the use of language in a certain context as well as the communication of intentions, thoughts and emotions, and to the symbolic aspects of communication (Cummings, 2009). Particularly, these processes are responsible for the comprehension of idioms, metaphors or irony, lexical-semantic processes, the understanding and production of prosody, discourse comprehension and production. They regulate communicative exchange by a developed and shared system of rules (Balconi, 2010; Bryan, 1995; Łojek, 2009). When present, dysfunctions in the area of pragmatic language can cause major obstacles which interfere with everyday life. Such dysfunctions hinder social communication by obscuring the intentions and emotions of others, making it difficult to keep track of the conversation topic or to comprehend inferred meanings (Jodzio et al., 2005). In speech production, they lead to focusing on details, interjecting inappropriate remarks or omitting important information and making it difficult to convey a message or an intention (Jodzio et al., 2005; Łojek, 2009). Thus, dysfunctions of higher level language skills disturb the communication ability and the relationships of affected people, leading to impairment of social interaction, or sometimes even to disintegration from society due to their inappropriate manners.

Language impairments in schizophrenia patients are widely described. Research shows deficits in phonological processing related to reading impairments (Arnott et al., 2011), in syntax or grammar (Condray et al., 2002; DeLisi, 2001; Semkovska, 2010) as well as in semantics (Vogel et al., 2009). By far the most marked linguistic deficits in schizophrenia occur in language and communication skills. Pragmatic impairments are known to compromise the comprehension of communicative intent (Tényi et al., 2002) and indirect speech act processing (Corcoran, 2003), and disturb the understanding of non-literal language (Corcoran et al., 1997; Drury et al., 1998; Kiang et al., 2007; Langdon et al., 2002; Pawełczyk et al., 2017), discourse (Andreasen et al., 1995; Kuperberg, 2010a, 2010b; McKenna and Oh, 2005) and prosody processing (Edwards et al., 2001; Martínez et al., 2015; Ross et al., 2001). Furthermore, schizophrenia patients exhibit lack of cohesion (Noel-Jorand et al., 1997), deficits in local and global coherence during story-telling (Perlini et al., 2012), produce irrelevant information and engage in derailments (Marini et al., 2008). They also display reduced context processing (Schenkel et al., 2005), impaired recognising and repairing of communicative failures (Bosco et al., 2012) and problems with referential communication (Champagne-Lavau et al., 2009). Higher level language deficits are already present at early stages of the illness in UHR (ultra-high risk for psychosis) and first episode (Pawełczyk et al., 2019) groups. Impaired abilities in comprehending implicit information, visuospatial processing and effectiveness of communication have been described in the UHR group (Pawełczyk et al., 2019) as well as poor pragmatic language (Sullivan et al., 2016), decreased narrative coherence and linguistic cohesion (Done and Leinonen, 2013) as well as lowered semantic coherence and syntactic complexity (Bedi et al., 2015). First episode of schizophrenia patients have also displayed language disturbances (Hoff et al., 1999) and pragmatic dysfunctions, including comprehension of implicit information, explanation of metaphors, discourse understanding, processing language information in the context of general knowledge and effectiveness of interpersonal communication (Pawełczyk et al., 2019). However, research describing a wide range of pragmatic language disturbances in patients with schizophrenia remain rather limited (Pawełczyk et al., 2018a).

Pragmatic dysfunctions are also observed in other mental health populations like neuropsychiatric disorders, personality disorders and depression (Bryan, 2014; Cummings, 2009, 2014). Some studies with depression patients also demonstrated difficulties in humour processing with respects to both affective and cognitive aspects (Uekermann et al., 2008) and metaphor processing (Iakimova et al., 2006). What is more, research has shown that patients with depression exhibit a tendency towards interpretational negativism of metaphors (Bartczak and Bokus, 2015), prosody comprehension and production difficulties (Yang et al., 2013) as well as problems with processing complex language information (Bartczak and Bokus, 2015).

Most studies have examined higher level language dysfunctions on different stages of schizophrenia (Bambini et al., 2016; Pawełczyk et al., 2019, 2018a) and some also disturbances of pragmatic language skills in depression (Yang et al., 2013). However, it is not clear whether pragmatic dysfunctions present in schizophrenia appear due to depression, co-occurring in course of schizophrenia (Castle and Bosanac, 2012) or are a core features of schizophrenia itself (Bambini et al., 2016). Although a few studies describe and compare some aspects of language in schizophrenia and depression patients (Lott et al., 2002) and one study (Meilijson et al., 2004) compares pragmatic language between cases of schizophrenia and a cohort of mixed anxiety-depression participants, among others, it is not clear 
whether there are differences in wide range of pragmatic language skills between the groups and it is not known if the groups differ in types of abnormalities or in their intensity. As it is vital to distinguish language and communication dysfunctions characteristic for schizophrenia, this preliminary study evaluates and compares a wide range of pragmatic language functions in schizophrenia and in depression patients who were experiencing psychopathological symptoms. It also analyses the relationship between pragmatic language skills and the presence of schizophrenia and depression symptoms. Our hypothesis is that some language and communication abilities will be lowered in schizophrenia patients when compared to those with depression, especially skills connected with inferencing, thinking and understanding. On the other hand, emotional dysfunctions could be more characteristic for depression.

\section{MATERIALS AND METHODS}

\section{Participants}

Eighty-two participants were enrolled: 41 patients with schizophrenia exacerbation (SCZ) and 41 participants with an episode of major depression (MD). The participants (both inpatients and outpatients) were enrolled consecutively after being assessed and diagnosed with either disorder by an experienced psychiatrist. The International Classification of Diseases, tenth edition (ICD-10) criteria of schizophrenia or a moderate/severe depressive episode (first or recurrent) were used for inclusion of participants. The severity of symptoms was assessed using validated clinical scales designed for both disorders. To increase the external validity of the results, background antipsychotic or antidepressant therapy and concomitant medications were chosen and titrated by the attending physician according to the Polish standards of pharmacotherapy of mental disorders (Jarema, 2015). The use of benzodiazepines and Z-drugs was allowed in both groups. The exclusion criteria for all participants were as follows: a history of neurological or chronic somatic disorder, head injury, or alcohol or substance abuse or dependence. Substance abuse was evaluated during the interview. All participants were right-handed, native speakers of Polish, Caucasian and of Polish nationality. Demographic information for all participants and clinical information for patients can be found in Tab. 1.

The exclusion criteria for all participants were as follows: a history of neurological or chronic somatic disorder, head injury, or alcohol or substance abuse or dependence. Substance abuse was evaluated during the interview.

\section{Procedure}

All the participants were tested during one session with a clinical neuropsychologist and one back-to-back session by a specialist psychiatrist. Higher order (pragmatic) language functions were assessed by the Right Hemisphere Language Battery (RHLB-PL) by E. Łojek (Bryan, 1995; Cummings, 2009; Łojek, 2007) and severity of the symptoms by the Positive and Negative Syndrome Scale (PANSS) (Kay et al., 1987; Rzewuska, 2002) and Hamilton Depression Rating Scale (HDRS) (Hamilton, 1960) respectively to the illness.

\section{Pragmatic language skills}

Pragmatic language was assessed by the RHLB-PL by Łojek (2007), this being the Polish version of the Right Hemisphere Language Battery by Bryan (1995). The battery was

\begin{tabular}{|c|c|c|c|}
\hline & $\begin{array}{c}\text { Schizophrenia patients }(n=41) \\
\text { Mean (SD) }\end{array}$ & $\begin{array}{c}\text { Depression patients }(n=41) \\
\text { Mean (SD) }\end{array}$ & $p$ \\
\hline Age [years] & $27(1.6)$ & $42(1.8)$ & $<0.001^{\text {a* }}$ \\
\hline Education [years] & $11.8(0.39)$ & $13.66(0.47)$ & $0.004^{b *}$ \\
\hline Sex (male) & $n=23(56.10 \%)$ & $n=15(36.59 \%)$ & $0.07^{c}$ \\
\hline HDRS-17 & - & $31.98(2.47)$ & - \\
\hline PANSS - Positive & $17.61(0.87)$ & - & - \\
\hline PANSS - Negative & $23.90(0.94)$ & - & - \\
\hline PANSS - General & $43.51(1.64)$ & - & - \\
\hline PANSS - Total & $85.27(3.12)$ & - & - \\
\hline \multicolumn{4}{|c|}{$\begin{array}{l}\text { SD - standard deviation of the mean; } \boldsymbol{p} \text { - probability value ( } p \text {-value); } \boldsymbol{n} \text { - number of participants; HDRS-17 - Hamilton Depression Rating Scale; PANSS - Positive and } \\
\text { Negative Syndrome Scale. } \\
\text { a } p \text {-value for Student's } t \text {-test. } \\
\text { b } p \text {-value for Mann-Whitney } U \text { test. } \\
\text { ' } p \text {-value for Chi² test. } \\
{ }^{*} \text { Indicates significant differences. }\end{array}$} \\
\hline
\end{tabular}

Tab. 1. Clinical and demographic information by group 
chosen for the study because it measures higher-order language functions and has been validated and standardised on Polish population (Cummings, 2009, 2017; Łojek, 2007). What is more, it is being used to assess pragmatic language in various populations e.g. dyslexia (Cappelli et al., 2018). The battery measures pragmatic abilities concerning context-bound linguistic as well as non-linguistic information processing and it requires the usage of verbal and non-verbal clues to understand intended messages. The RHLB-PL comprises eight tests: Inferential Meaning, Lexical-Semantics, Written Metaphor, Picture Metaphor, Humour, Emotional Prosody, Linguistic Prosody and Discourse Analysis. The factor analysis of the RHLB-PL results distinguishes five factors: Language Factor, Perceptual-Logical Factor, Cognitive Factor, Socio-Emotional Factor and Self-Control Factor. In the Inferential Meaning test, an examinee responds to four questions checking the comprehension of implicit information given in each of four narratives. In the Lexical-Semantic test, a participant is asked to point to the drawing representing the target item named by the examiner. For each item, there are five additional pictures associated with the item: two semantic co-ordinates, a functional associate, phonological and visual controls. In the Humour test, the subject chooses the correct punchline for 10 jokes. Apart from the correct one, the responses include a straight ending of neutral content and surprise ending irrelevant to the body of the joke. The number of inappropriate remarks and comments made by the examinee during the Humour and Inferential Meaning tests are noted (the Commentary test). In the Written Metaphor test, the examinee listens to a metaphorical sentence and is asked to choose a correct explanation from three sentences representing possible meanings: a correct metaphorical meaning, a literal meaning and an inappropriate meaning; the subject is then asked to give a personal interpretation of the metaphor, and answers are classified as correct, abstract incorrect or concrete incorrect (the Written Metaphor Explanation test). In the Picture Metaphor test, the participant is asked to point to the picture that matches the meaning of the metaphor read by the examiner. There are four pictures in each set: one representing the correct metaphorical meaning, another the literal meaning, and two control pictures depicting one aspect of the sentence. The accuracy of the explanation of the metaphors by the examinee is also assessed in the Picture Metaphor Explanation test. In the Polish version of the RHLB, the prosody tests comprise 15 nonsense sentences read and recorded by a professional speaker. The sentences are read randomly with three emotional tones (happy, angry and sad) for the Emotional Prosody test, and then are read randomly with intonations expressing statement, question and order for the Linguistic Prosody test. After listening to each sentence, the subject points to the written name of the emotions or linguistic intonations. The Prosody tests are presented from CD. The Discourse Analysis test evaluates two-way interaction or conversation and appropriateness of behaviour in communication settings. Apart from the subscales, there are also five factors in the RHLB-PL. The Language Factor is expressed as the sum of scores for Written Metaphors, Language Prosody and Humour. This factor may be a measure of the general level of cognitive functioning, but it also has a powerful linguistic component and requires the capacity to process linguistic information in the context of the data provided in the message. The Cognitive Factor is expressed as the sum of scores for the Inference Test, Interpretation of Picture Metaphors and Interpretation of Written Metaphors. This factor requires the capacity to process linguistic information in the context of broader knowledge of the world. The Perceptual-Logical Factor requires the capacity to process visuospatial information and is expressed as the sum of converted scores for graphic Metaphors and the Lexico-Semantic Scale. The Socio-Emotional Factor requires the capacity to communicate with people and is expressed as the sum of converted scores for Discourse Analysis and Emotional Prosody. The Behavioural Self-Control Factor requires the capacity for behavioural control when communicating with other people and is the equivalent of the converted score for the Commentary Test (Łojek, 2009, 2007).

\section{Psychopathological symptoms assessment}

The severity of schizophrenia symptoms was evaluated with the PANSS (Kay et al., 1987; Rzewuska, 2002), a standardised, clinical interview which was administered by a specialist psychiatrist. It constitutes four scales measuring positive and negative symptoms, their differential, and the general severity of illness. Of the 30 parameters assessed, seven constitute a Positive Scale (score range 7-49), seven a Negative Scale (score range 7-49), and the remaining 16 a General Psychopathology Scale (score range 16-112). The severity of depression was assessed by the evaluator using the HDRS (Hamilton, 1967) a 17-item scale. Nine items are scored on a five-point ( 0 to 4$)$ ordinal scale and eight items are scored on a three-point $(0,1,2)$ scale. A total score is calculated as sum of the 17 items and can range from 0 to 52 . Higher scores reflect more severe depression. The authors assert that all procedures contributing to this work comply with the ethical standards of the relevant national and institutional committees on human experimentation and with the Helsinki Declaration of 1975, as revised in 2008 and the study received approval from the Ethical Committee of the Medical University of Lodz.

\section{Statistical analysis}

Differences between the groups in variables characterising demographic, socioeconomic and clinical aspects of the study population were assessed using Student's $t$-test, Mann-Whitney $U$ test, chi-squared test or Fisher's test depending on the met assumptions. The study groups differed significantly in age and years of education - the variables also known to be related to language performance. Thus, one-way analysis of covariance (ANCOVA) controlling for age and years of education was used to assess 
differences between the study groups in pragmatic language skills. Eta squared was used as a measure of effect size, and it was interpreted in the event that statistically significant differences were observed between the groups. The associations between HDRS, PANSS and pragmatic language (RHLB subtests) were evaluated using Kendall's tau- $b$ coefficient or Pearson's product-moment correlation coefficient, depending on the met assumptions. Benjamini-Hochberg correction was used to control for multiple comparisons. A significance level of 0.05 was applied.

\section{RESULTS}

\section{Demographic, clinical and outcome characteristics}

Demographic and clinical characteristics are summarised in Tab. 1. Participants of the two groups differed with regard to age and years of education. All of them were right-handed and native speakers of Polish.

\section{Association of higher-order language skills and clinical symptoms}

No associations were found between PANSS symptomatology and pragmatic language (measured by subtests of RHLB) (Benjamini-Hochberg corrected $p>0.05$ ). However, correlations were found between HDRS score and most of the RHLB subtests (Benjamini-Hochberg corrected $p>0.05$ ) except for Commentary and Picture Metaphor Explanation tests. The analyses are presented in Tab. 2.

\section{Difference in higher-order language skills}

Analysis of covariance (ANCOVA) assessed groups differences for each subtest of RHLB, covering age and education level. For each subscale with intergroup differences, a standardized estimate of effect-size impairment was provided: (eta) $\eta^{2}$. The metric of small $\eta^{2}=0.01$, medium $\eta^{2}=0.06$, and large effect-size $\eta^{2}=0.14$ impairment was used. The participants showed deficits in the moderate-large

\begin{tabular}{|c|c|c|c|c|c|c|c|c|c|c|}
\hline \multirow[b]{2}{*}{ RHLB-PL } & \multicolumn{2}{|c|}{ HDRS-17 } & \multicolumn{2}{|c|}{ PANSS-P } & \multicolumn{2}{|c|}{ PANSS-N } & \multicolumn{2}{|c|}{ PANSS-G } & \multicolumn{2}{|c|}{ PANSS-T } \\
\hline & $\begin{array}{c}\text { Kendall's } \\
\text { tau- } b\end{array}$ & $\begin{array}{c}\text { B-H } \\
p \text {-value }\end{array}$ & $\begin{array}{c}\text { Kendall's } \\
\text { tau- } b\end{array}$ & $\begin{array}{c}\text { B-H } \\
p \text {-value }\end{array}$ & $\begin{array}{c}\text { Kendall's } \\
\text { tau- } b\end{array}$ & $\begin{array}{c}\text { B-H } \\
p \text {-value }\end{array}$ & $\begin{array}{c}\text { Kendall's } \\
\text { tau- } b\end{array}$ & $\begin{array}{c}\text { B-H } \\
p \text {-value }\end{array}$ & $\begin{array}{c}\text { Kendall's } \\
\text { tau- } b\end{array}$ & $\begin{array}{c}\text { B-H } \\
p \text {-value }\end{array}$ \\
\hline Inferential Meanings & -0.456 & $0.001^{*}$ & 0.054 & 0.792 & 0.123 & 0.573 & 0.042 & 0.909 & 0.068 & 0.738 \\
\hline Lexical-Semantics & -0.397 & $0.004^{*}$ & 0.246 & 0.267 & 0.162 & 0.573 & 0.131 & 0.542 & 0.182 & 0.343 \\
\hline Humour & -0.309 & $0.025^{*}$ & -0.134 & 0.551 & -0.089 & 0.601 & -0.232 & 0.259 & -0.192 & 0.343 \\
\hline Commentary & 0.198 & 0.133 & 0.193 & 0.361 & 0.188 & 0.573 & 0.18 & 0.387 & 0.176 & 0.343 \\
\hline Picture Metaphor & -0.343 & $0.012^{*}$ & 0.113 & 0.613 & 0.179 & 0.573 & 0.114 & 0.548 & 0.148 & 0.426 \\
\hline Written Metaphor & -0.346 & $0.012^{*}$ & -0.073 & 0.770 & -0.089 & 0.601 & -0.039 & 0.909 & -0.092 & 0.671 \\
\hline $\begin{array}{l}\text { Picture Metaphor } \\
\text { Explanation }\end{array}$ & -0.203 & 0.133 & -0.016 & 0.890 & 0.125 & 0.573 & 0.001 & 0.991 & 0.04 & 0.878 \\
\hline $\begin{array}{l}\text { Written Metaphor } \\
\text { Explanation }\end{array}$ & -0.272 & $0.048^{*}$ & 0.03 & 0.852 & 0.157 & 0.573 & -0.017 & 0.941 & 0.034 & 0.878 \\
\hline Emotional Prosody & -0.383 & $0.003^{*}$ & -0.041 & 0.835 & 0.065 & 0.601 & -0.03 & 0.909 & -0.089 & 0.659 \\
\hline Linguistic Prosody & -0.401 & $0.003^{*}$ & -0.091 & 0.681 & -0.062 & 0.601 & -0.139 & 0.447 & -0.101 & 0.659 \\
\hline Discourse Analysis & -0.444 & $0.003^{*}$ & -0.24 & 0.267 & -0.061 & 0.601 & -0.253 & 0.216 & -0.228 & 0.332 \\
\hline Language Factor & -0.384 & $0.003^{*}$ & -0.145 & 0.543 & -0.077 & 0.601 & -0.229 & 0.259 & -0.2 & 0.343 \\
\hline Cognitive Factor & -0.457 & $0.001^{*}$ & -0.062 & 0.770 & 0.124 & 0.573 & -0.062 & 0.835 & -0.011 & 0.983 \\
\hline Perceptual-Logical Factor & -0.459 & $0.001^{*}$ & -0.202 & 0.283 & -0.073 & 0.601 & -0.275 & 0.216 & -0.226 & 0.332 \\
\hline Socio-Emotional Factor & -0.463 & $0.001^{*}$ & 0.272 & 0.267 & 0.227 & 0.573 & 0.165 & 0.387 & 0.228 & 0.332 \\
\hline Self-Control Factor & -0.198 & 0.134 & -0.242 & 0.267 & -0.221 & 0.573 & -0.172 & 0.387 & -0.189 & 0.343 \\
\hline
\end{tabular}

RHLB -PL - Right Hemisphere Language Battery - Polish version; HDRS-17 - Hamilton Depression Rating Scale; PANSS - Positive and Negative Syndrome Scale; B-H - Benjamini-Hochberg correction.

* Significant correlations were marked. 
(0.047-0.984) range on language skills. Tab. 3 displays the subtest of the RHLB and its subscales. The results show that schizophrenia and depression patients varied in all RHLB-PL subtests apart from Lexical-Sematic, Commentary and Self-refrain Factor. Patients with schizophrenia scored significantly lower in all differentiating subtest except for Emotional Prosody in which they scored higher. Results are presented in Tab. 3.

\section{DISCUSSION}

The present study examines differences in a wide range of higher-order language functions present in schizophrenia and depression patients, while controlling for age and education; it also looks at the relationship between psychopathological symptoms, both in schizophrenia and depression, and language and communication skills. Our hypothesis that patients with schizophrenia and depression differ from each other in superior communicative functions was partly confirmed: the patients with schizophrenia demonstrated an overall lower level of language and communication abilities, as described by the overall result of the RHLB-PL $\left(\eta^{2}=0.868\right)$ and those of most of its' subtests. The participants with schizophrenia displayed lower abilities with regard to comprehension of implicit information (Inferential Meaning), understanding humour (Humour), processing metaphors (Written and Picture Metaphors; Picture and Written Metaphor Explanation) as well as comprehending discourse (Discourse) and linguistic prosody (Linguistic Prosody) than those with depression $\left(y^{2}=0.064-0.367\right)$. What is more, those with schizophrenia demonstrated a significantly poorer capacity to process linguistic information in the context of oral message (Language Factor) and in the context of general knowledge (Cognitive Factor) as well as processing visualspatial information (Perceptual-Logical Factor) and abilities to efficiently communicate (Socio-Emotional Factor) with people $\left(\eta^{2}=0.677-0.984\right)$. On the other hand, emotional prosody understanding (Emotional Prosody) was better in schizophrenia patients $\left(\eta^{2}=0.136\right)$ and the patient groups

\begin{tabular}{|c|c|c|c|c|c|}
\hline RHLB-PL subtests & $\begin{array}{l}\text { Patients with schizophrenia } \\
\qquad(n=41) \\
\text { Mean }^{\mathrm{a}}(S E)\end{array}$ & $\begin{array}{c}\text { Patients with depression } \\
(n=41) \\
\text { Mean }^{\mathrm{a}}(S E)\end{array}$ & $F(d f)$ & $p$ & Eta squared \\
\hline Inferential Meaning & $13.41(1.673)$ & $15.41(0.774)$ & $44.83(1.78)$ & $<0.001^{*}$ & 0.365 \\
\hline Lexical-Semantic & $12.61(0.542)$ & $12.49(0.506)$ & $1.575(1.78)$ & 0.213 & - \\
\hline Humour & $8.9(1.715)$ & $9.71(0.461)$ & $12.816(1.78)$ & $0.001^{*}$ & 0.141 \\
\hline Commentary & $0.98(2.454)$ & $0.32(0.471)$ & $1.977(1.78)$ & 0.164 & - \\
\hline Written Metaphor & $9.63(1.178)$ & $9.85(0.358)$ & $11.039(1.78)$ & $0.001^{*}$ & 0.124 \\
\hline Picture Metaphor & $8.8(1.926)$ & $9.85(0.475)$ & $5.330(1.78)$ & $0.024^{*}$ & 0.064 \\
\hline Written Metaphor Explanation & $7.6(1.997)$ & $9.95(0.218)$ & $49.768(1.77)$ & $<0.001^{*}$ & 0.393 \\
\hline Picture Metaphor Explanation & $7.39(1.842)$ & $9.9(0.300)$ & $48.832(1.78)$ & $<0.001^{*}$ & 0.385 \\
\hline Emotional Prosody & $14.13(1.588)$ & $13.00(1.025)$ & $12.077(1.77)$ & $0.001^{*}$ & 0.136 \\
\hline Linguistic Prosody & $13.01(2.379)$ & $13.99(0.877)$ & $3.827(1.77)$ & $0.054^{*}$ & 0.047 \\
\hline Discourse Analysis & $47.58(9.777)$ & $57.2(2.348)$ & $44.565(1.77)$ & $<0.001^{*}$ & 0.367 \\
\hline Overall result & $82.1(2.34)$ & $96.6(2.31)$ & $15.32(1)$ & $<0.001^{*}$ & 0.140 \\
\hline Language Factor & $23.8(0.579)$ & $27.0(0.560)$ & $12.51(1)$ & $<0.001^{*}$ & 0.109 \\
\hline Cognitive Factor & $16.7(0.595)$ & $29.1(0.586)$ & $176.968(1)$ & $<0.001^{*}$ & 0.666 \\
\hline Perceptual-Logical Factor & $12.9(0.549)$ & $18.0(0.531)$ & $34.03(1)$ & $<0.001^{*}$ & 0.275 \\
\hline Socio-Emotional Factor & $17.3(0.435)$ & $15.4(0.428)$ & $8.24(1)$ & $0.005^{*}$ & 0.092 \\
\hline Self-Control/-Restrain Factor & $8.73(2.56)$ & $8.41(2.35)$ & $0.327(1.78)$ & 0.569 & - \\
\hline
\end{tabular}


did not vary in basic language skills (Lexical Semantic) or in their ability to self refrain (Self-Control/-Restrain Factor, Commentary). No correlation was observed between pragmatic language skills and schizophrenia symptoms, however, there was an association between pragmatic language and severity of depression.

Our present observations are difficult to compare with those of relevant studies, as there are very limited number of studies comparing such a wide range of higherlevel language functions in schizophrenia and depression patients and methods used in those research are different. However, they are in line with research showing linguistic differences between the groups in production of illogical statements and "degree of linguistic abnormality" (Lott et al., 2002), in information references and reference failures (Rubino et al., 2011) as well as metaphor comprehension (Iakimova et al., 2006). They are also coherent with the study results (Meilijson et al., 2004) exhibiting pragmatic language differences though between schizophrenia and mixed anxiety-depression participants and evaluating pragmatic language by other assessment protocol. Despite these methodological differences, the outcomes of mentioned studies, including the present study, suggest discrepancy in pragmatic language ability between schizophrenia and depression patients. Interestingly, patients with schizophrenia experience more serious language and communication disturbances than those with depression when their results are compared to maximum results that can be obtained on all RHLB-PL subscales, but they comprehend emotional prosody much better. Even through emotional prosody seems to be disturbed in both groups of patients (Edwards et al., 2001; Péron et al., 2011), this disturbance is less serious in people with schizophrenia, at least in our study, and may suggest stronger association between prosody comprehension and mood disturbances. Also, the group with schizophrenia is more heterogeneous when compared to the other with depression which may suggest greater variety of certain pragmatic skills among schizophrenia patients. Though, due to rather small number of participants and lack of healthy controls, it needs further studies.

The results obtained also showed no significant correlations between pragmatic language skills and schizophrenia symptoms (e.g. hallucinations, delusions) measured by the PANSS, which is coherent with studies showing no correlation between language comprehension and positive symptoms (Condray et al., 1995), syntactic complexity and psychotic symptoms (Morice and Igram, 1983) as well as the lack of association between schizophrenia psychopathology and linguistic deficits (Lott et al., 2002) and pragmatic language (Meilijson et al., 2004). On the other hand, they are inconsistent with some other research on schizophrenia individuals showing an association between negative symptoms and metaphor processing, thought disorder and metaphor understanding (Iakimova et al., 2006) as well as metaphor comprehension, social functioning and general psychopathology (Piovan et al., 2016) and pragmatic language with psychopathology (Bambini et al., 2016). Although the literature is inconsistent, our present findings as well as Lott's et al. (2002), Condray's et al. (1995), Morice and Ingram's (1983) and Meilijson et al. (2004) suggest that language skills could be independent of schizophrenia psychopathology. There are also studies showing pragmatic deficits at early stages of the illness, at the prodromal phase (Done and Leinonen, 2013; Pawełczyk et al., 2019; Sullivan et al., 2016), and in first degree relatives with no history of psychotic symptoms and beyond the usual age of risk (Pawełczyk et al., 2018b), which might suggest that some language and communication disturbances are associated with the illness itself not with the state and they comprise separate traits. However, this hypothesis is very preliminary and would need further research for example examining pragmatic language skills in remitted patients with schizophrenia.

Additionally, our results showed significant association between pragmatic language and depression. Most of the subtests, excluding Commentary and Picture Metaphor Explanation tests, correlated with severity of depression. It suggests association between pragmatic deficits and lowering of the mood. These outcomes are in line with those of other studies (Iakimova et al., 2006; Wray, 2011); although Wray's (2011) was carried out on young people with autism spectrum disorder so our study used a different sample. What is more, both studies used other methods of pragmatic language evaluation. Nevertheless, the research suggests a link between depression and higher level language dysfunctions. Our observation that there is no significant correlation between ability to self-refrain and depression might suggest that self-control and mood lowering are independent; however, this observation is inconsistent with other studies describing association between depression and self-control of food consumption (Privitera et al., 2015) and correlation between self-control and depression in adolescents (Li et al., 2015). However, these differences might have appeared due to sample differences, variety of assessment methods used or influence of confounding factors like executive or cognitive functions. Our results also show no correlation between explanation of picture metaphors and depression together with association between written metaphor explanation and depression. This difference might have appeared due to the weaker influence of mood lowering on processing of visual metaphors then verbal ones, which might be a result of visual information processing via two separate pathways, image and verbal, and strengthening the process of encoding (Paivio, 1991) or due to more attention-inducing qualities of pictures than words (Mashal and Kasirer, 2012). In addition, perceptual metaphor comprehension is supposed to develop earlier in life than, and as such may be mastered earlier and for a longer time and become less susceptible to mood disturbances. Nevertheless, such hypothesis needs further studies. 
The results obtained in our study offer an insight into language and communication failures made by people with schizophrenia. They highlight pragmatic language differences between schizophrenia and depression patients, suggesting that the depth of the dysfunctions might be specific for schizophrenia. Nevertheless, they cannot conclusively indicate whether pragmatic disturbances observed in our study reflect a trait of schizophrenia or a comorbid presentation in these two diseases. As research shows an overlap in the symptoms and genetic risk factors between schizophrenia and depression, and also demonstrates shared pathophysiological mechanisms in both disorders, pragmatic impairments might also represent a common trait of these patients (Gatt et al., 2015). The results obtained may also suggest that the pragmatic language impairments profiles of the assessed patients overlap but with differences in the intensity of the dysfunctions. However, to address such issue, depressed and schizophrenia participants should be evaluated and compared with a group of healthy participants in future studies and depression should be controlled.

The results of this study showing differences between patients with schizophrenia and depression in some higherlevel language skills could not be attributed to age, education level, sex and basic language skills like naming. However, as language difficulties may reflect the influence of general intellectual functions as well as executive and cognitive functions (Docherty, 2005), their method of control should be addressed in some other study. On the other hand, it could be assumed that level of education exhibits general intellectual level and as such was to some extend controlled in this research. Further systematic studies of pragmatic language dysfunctions in various psychiatric populations are needed as language evaluation might help in differential diagnostic processes, especially in disorders with overlapping psychopathology, contribute to early detection of the diseases and shortening duration of untreated psychiatric disorders. What is more, a thorough pragmatic language assessment and recognition of any disturbances could support the development of new neuropsychological and neurolinguistic strategies for language and communication disturbances (Clegg et al., 2007) to help patients maintain their daily living and work activities. It would also be worth considering speech and language therapy in mental health populations, but this needs more study. Further studies linking higher order language dysfunctions and with neuroimaging techniques could clarify any association between pragmatic language disturbances in mental disorders and brain pathologies. A better understanding of pragmatic language dysfunctions together with results gleaned from neuroimaging studies could provide new insights into brain dysfunctions in neuropsychiatric diseases.

This study has a number of limitations. No evaluation of premorbid intellectual functioning, cognitive and executive functions was performed, so it is not clear whether differences between the assessed groups are only attribut- cognitive deficit or executive/cognitive dysfunctions. Furthermore, basic language skills (verbal fluency, comprehension) and social cognition were not evaluated and controlled for in the study. Also, poor effort was not controlled for, however, there were no clinical signs of intergroup differences in this regard. What is more, there was no assessment of depression in the schizophrenia patients, and the influence of mood disorder on intergroup differences was not controlled for. In addition, the RHLB-PL battery was not intended for patients with mental disorders and has not been validated for the tested groups. However, Bryan (1995), Łojek (2007) and Cummings $(2009,2017)$ note that it can be utilise for the evaluation of pragmatic dysfunction and both schizophrenia and depression patients are known to perform poorly on tests measuring these language functions (Iakimova et al., 2006). In addition, patients were using medication (antipsychotic or antidepressant relevant to the symptoms) at the time of testing, which might have influenced their performance on RHLB-PL. Also, the duration of the illnesses was not measured, and this could have confounded the results of test battery.

To sum up, the results of this preliminary study, although limited in their generalizability, suggest that pragmatic language skills could be more seriously disturbed in patients with schizophrenia than with depression. They also imply that pragmatic language dysfunctions may be independent of schizophrenia symptoms being a possible trait of the illness but associated with depression symptoms. To our knowledge, this study is the first to comprehensively examine and compare wide range of pragmatic language skills in schizophrenia and depression patients using a standardized test battery. In addition, as one of the few shows independence of pragmatic dysfunctions of schizophrenia symptoms and their association with mood disorder. Further studies on higher-level language skills in mental health groups could help to identify dysfunctions specific for schizophrenia and could give a better understanding of pragmatic disturbances in mental disorders as whole.

\section{Conflict of interest}

All the authors declare no conflict of interest.

\section{References}

Andreasen NC, Arndt S, Alliger R et al.: Symptoms of schizophrenia. Methods, meanings, and mechanisms. Arch Gen Psychiatry 1995; 52: 341-351.

Arnott W, Sali L, Copland D: Impaired reading comprehension in schizophrenia: evidence for underlying phonological processing deficits. Psychiatry Res 2011; 187: 6-10.

Balconi M: Biological basis of linguistisc and communicative systems: from neurolinguistics to neuropragmatics. In: Balconi M (ed.): Neuropsychology of Communication. Springer-Verlag Italia, Milan 2010: 3-27.

Bambini V, Arcara G, Bechi M et al.: The communicative impairment as a core feature of schizophrenia: frequency of pragmatic deficit, cognitive substrates, and relation with quality of life. Compr Psychiatry 2016; 71: 106-120. 
Bartczak M, Bokus B: Cognitive representations (Metaphorical Conceptualizations) of past, future, joy, sadness and happiness in depressive and non-depressive subjects: cognitive distortions in depression at the level of notion. J Psycholinguist Res 2015; 44: 159-185.

Bedi G, Carrillo F, Cecchi GA et al.: Automated analysis of free speech predicts psychosis onset in high-risk youths. NPJ Schizophr 2015; 1: 15030

Bosco FM, Bono A, Bara BG: Recognition and repair of communicative failures: the interaction between Theory of Mind and cognitive complexity in schizophrenic patients. J Commun Disord 2012; 45: 181-197.

Bryan K: Psychiatric disorders and communication. In: Cummings L (ed.): The Cambridge Handbook of Communication Disorders. Cambridge University Press, Cambridge 2014: 300-318.

Bryan K: The Right Hemisphere Language Battery. $2^{\text {nd }}$ ed., Whurr Publishers, Ltd, London 1995.

Cappelli G, Noccetti S, Arcara G et al.: Pragmatic competence and its relationship with the linguistic and cognitive profile of young adults with dyslexia. Dyslexia 2018; 24: 294-306.

Castle D, Bosanac P: Depression and schizophrenia. Adv Psychiatr Treat 2012; 18: 280-288

Champagne-Lavau M, Fossard M, Martel G et al.: Do patients with schizophrenia attribute mental states in a referential communication task? Cogn Neuropsychiatry 2009; 14: 217-239.

Clegg J, Brumfitt S, Parks RW et al.: Speech and language therapy intervention in schizophrenia: a case study. Int J Lang Commun Disord 2007; 42 Suppl 1: 81-101.

Condray R, van Kammen DP, Steinhauer SR et al.: Language comprehension in schizophrenia: trait or state indicator? Biol Psychiatry 1995; 38: 287-296.

Condray R, Steinhauer SR, van Kammen DP et al.: The language system in schizophrenia: effects of capacity and linguistic structure. Schizophr Bull 2002; 28: 475-490.

Corcoran R: Inductive reasoning and the understanding of intention in schizophrenia. Cogn Neuropsychiatry 2003; 8: 223-235.

Corcoran R, Cahill C, Frith CD: The appreciation of visual jokes in people with schizophrenia: a study of 'mentalizing' ability. Schizophr Res 1997; 24: 319-327.

Cummings L: Clinical Pragmatics. Cambridge University Press, New York 2009.

Cummings L: Pragmatic disorders across the life span. In: Cummings L: Pragmatic Disorders. Springer, Dordrecht 2014: 31-65.

Cummings L (ed.): Research in Clinical Pragmatics. Springer, 2017.

DeLisi LE: Speech disorder in schizophrenia: review of the literature and exploration of its relation to the uniquely human capacity for language. Schizophr Bull 2001; 27: 481-496.

Docherty NM: Cognitive impairments and disordered speech in schizophrenia: thought disorder, disorganization, and communication failure perspectives. J Abnorm Psychol 2005; 114: 269-278.

Done DJ, Leinonen E: Pragmatic use of language by children who develop schizophrenia in adult life. Schizophr Res 2013; 147: 181-186.

Drury VM, Robinson EJ, Birchwood M: 'Theory of mind' skills during an acute episode of psychosis and following recovery. Psychol Med 1998; 28: 1101-1112.

Edwards J, Pattison PE, Jackson HJ et al.: Facial affect and affective prosody recognition in first-episode schizophrenia. Schizophr Res 2001; 48: 235-253.

Gatt JM, Burton KL, Williams LM et al.: Specific and common genes implicated across major mental disorders: a review of meta-analysis studies. J Psychiatr Res 2015; 60: 1-13.

Hamilton M: A rating scale for depression. J Neurol Neurosurg Psychiatry 1960; 23: 56-62.

Hamilton M: Development of a rating scale for primary depressive illness. Br J Soc Clin Psychol 1967; 6: 278-296.

Hoff AL, Sakuma M, Wieneke M et al.: Longitudinal neuropsychological follow-up study of patients with first-episode schizophrenia. Am J Psychiatry 1999; 156: 1336-1341.
Iakimova G, Passerieux C, Hardy-Baylé MC: La compréhension des métaphores dans la schizophrénie et la dépression. Une approche expérimentale. [The understanding of metaphors in schizophrenia and depression. An experimental approach]. Encephale 2006; 32: $995-1002$.

Jarema M (ed.): Standardy leczenia farmakologicznego niektórych zaburzeń psychicznych. Via Medica, Gdańsk 2015.

Jodzio K, Łojek E, Bryan K: Functional and neuroanatomical analysis of extralinguistic disorders in right hemisphere-damaged patients. Psychology of Language and Communication 2005; 9: 55-73.

Kay SR, Fiszbein A, Opler LA: The Positive and Negative Syndrome Scale (PANSS) for schizophrenia. Schizophr Bull 1987; 13: 261-276.

Kiang M, Light GA, Prugh J et al.: Cognitive, neurophysiological, and functional correlates of proverb interpretation abnormalities in schizophrenia. J Int Neuropsychol Soc 2007; 13: 653-663.

Kuperberg GR: Language in schizophrenia Part 1: an introduction. Lang Linguist Compass 2010a; 4: 576-589.

Kuperberg GR: Language in schizophrenia Part 2: What can psycholinguistics bring to the study of schizophrenia...and vice versa? Lang Linguist Compass 2010b; 4: 590-604.

Langdon R, Davies M, Coltheart M: Understanding minds and understanding communicated meanings in schizophrenia. Mind Lang 2002; 17: 68-104.

Li JB, Delvecchio E, Lis A et al.: Parental attachment, self-control, and depressive symptoms in Chinese and Italian adolescents: test of a mediation model. J Adolesc 2015; 43: 159-170.

Lott PR, Guggenbühl S, Schneeberger A et al.: Linguistic analysis of the speech output of schizophrenic, bipolar, and depressive patients. Psychopathology 2002; 35: 220-227.

Łojek E: Imaging communication in the brain. In: Bryan K (ed.): Interdisciplinary Communication Studies. Vol. 1. Communication in Healthcare. Peter Lang European Academic Publishers, London 2009: 1-65.

Łojek E: RHLB-PL - Bateria Testów do Badania Funkcji Językowych i Komunikacyjnych Prawej Półkuli Mózgu. Podręcznik. Pracownia Testów Psychologicznych Polskiego Towarzystwa Psychologicznego, Warszawa 2007.

Marini A, Spoletini I, Rubino IA et al.: The language of schizophrenia: an analysis of micro and macrolinguistic abilities and their neuropsychological correlates. Schizophr Res 2008; 105: 144-155.

Martínez A, Felizzola Donado CA, Matallana Eslava DL: [Spontaneous speech prosody and discourse analysis in schizophrenia and Fronto Temporal Dementia (FTD) patients]. Rev Colomb Psiquiatr 2015; 44: 13-19.

Mashal N, Kasirer A: Principal component analysis study of visual and verbal metaphoric comprehension in children with autism and learning disabilities. Res Dev Disabil 2012; 33: 274-282.

McKenna PJ, Oh TM: Schizophrenic Speech. Cambridge University Press, Cambridge 2005.

Meilijson SR, Kasher A, Elizur A: Language performance in chronic schizophrenia: a pragmatic approach. J Speech Lang Hear Res 2004; 47: 695-713.

Morice RD, Igram JC: Language complexity and age of onset of schizophrenia. Psychiatry Res 1983; 9: 233-242.

Noel-Jorand MC, Reinert M, Giudicelli S et al.: A new approach to discourse analysis in psychiatry, applied to a schizophrenic patient's speech. Schizophr Res 1997; 25: 183-198.

Paivio A: Dual coding theory: retrospect and current status. Can J Psychol 1991; 45: 255-287.

Pawełczyk A, Kotlicka-Antczak M, Łojek E et al.: Preliminary study of higher-order language and extralinguistic impairments in individuals with high clinical risk of psychosis and first episode of schizophrenia. Early Interv Psychiatry 2019; 13: 369-378.

Pawełczyk A, Kotlicka-Antczak M, Łojek E et al.: Schizophrenia patients have higher-order language and extralinguistic impairments. Schizophr Res 2018a; 192: 274-280.

Pawełczyk A, Łojek E, Pawełczyk T: Metaphor processing in schizophrenia patients: a study of comprehension and explanation of metaphors. Psychology of Language and Communication 2017; 21: 287-305. 
Pawełczyk A, Łojek E, Żurner N et al.: Higher-order language dysfunctions as a possible neurolinguistic endophenotype for schizophrenia: evidence from patients and their unaffected first degree relatives. Psychiatry Res 2018b; 267: 63-72.

Perlini C, Marini A, Garzitto M et al.: Linguistic production and syntactic comprehension in schizophrenia and bipolar disorder. Acta Psychiatr Scand 2012; 126: 363-376.

Péron J, El Tamer S, Grandjean D et al.: Major depressive disorder skews the recognition of emotional prosody. Prog Neuropsychopharmacol Biol Psychiatry 2011; 35: 987-996.

Piovan C, Gava L, Campeol M: Theory of Mind and social functioning in schizophrenia: correlation with figurative language abnormalities, clinical symptoms and general intelligence. Riv Psichiatr 2016; 51: 20-29.

Privitera GJ, McGrath HK, Windus BA et al.: Eat now or later: selfcontrol as an overlapping cognitive mechanism of depression and obesity. PloS One 2015; 10: e0123136.

Ross ED, Orbelo DM, Cartwright J et al.: Affective-prosodic deficits in schizophrenia: comparison to patients with brain damage and relation to schizophrenic symptoms [corrected]. J Neurol Neurosurg Psychiatry 2001; 70: 597-604.

Rubino IA, D'Agostino L, Sarchiola L et al.: Referential failures and affective reactivity of language in schizophrenia and unipolar depression. Schizophr Bull 2011; 37: 554-560.

Rzewuska M: Validity and reliability of the Polish version of the Positive and Negative Syndrome Scale (PANSS). Int J Methods Psychiatr Res 2002; 11: 27-32.
Schenkel LS, Spaulding WD, Silverstein SM: Poor premorbid social functioning and theory of mind deficit in schizophrenia: evidence of reduced context processing? J Psychiatr Res 2005; 39: 499-508.

Semkovska M: Agrammatism in a case of formal thought disorder: beyond intellectual decline and working memory deficit. Neurocase 2010; 16: 37-49.

Sullivan SA, Hollen L, Wren Y et al.: A longitudinal investigation of childhood communication ability and adolescent psychotic experiences in a community sample. Schizophr Res 2016; 173: 54-61.

Tényi T, Herold R, Szili IM et al.: Schizophrenics show a failure in the decoding of violations of conversational implicatures. Psychopathology 2002; 35: 25-27.

Uekermann J, Channon S, Lehmkamper C et al.: Executive function, mentalizing and humor in major depression. J Int Neuropsychol Soc 2008; 14: 55-62.

Vogel AP, Chenery HJ, Dart CM et al.: Verbal fluency, semantics, context and symptom complexes in schizophrenia. J Psycholinguist Res 2009; 38: 459-473.

Wray EA: The relationship between pragmatic language skills and depressive symptoms in children and adolescents with autism spectrum disorder. A dissertation presented to the graduate school of the University of Florida in partial fulfillment of the requirements for the degree of doctor of philosophy. University of Florida, 2011.

Yang Y, Fairbairn C, Cohn JF: Detecting depression severity from vocal prosody. IEEE Trans Affect Comput 2013; 4: 142-150. 